\title{
AMPK signalling in health and disease
}

David Carling, MRC Clinical Sciences Centre, Hammersmith Hospital, Imperial College, London W12 ONN UK

Email: dcarling@imperial.ac.uk

\begin{abstract}
In eukaryotic cells AMP-activated protein kinase (AMPK) plays a major role in regulating cellular energy balance. AMPK responds to changes in intracellular adenine nucleotide levels, being activated by an increase in AMP/ADP relative to ATP. Activation of AMPK increases the rate of catabolic (ATP-generating) pathways and decreases the rate of anabolic (ATP-utilising) pathways. In addition to its role in maintaining intracellular energy balance, AMPK regulates whole body energy metabolism. Given its key role in controlling energy homeostasis, AMPK has attracted widespread interest as a potential therapeutic target for metabolic diseases, including type 2 diabetes and, more recently, cancer. Here I review the regulation of AMPK and its potential as a target for therapeutic intervention in human disease.
\end{abstract}

\section{Introduction}

The hydrolysis of ATP to ADP provides the energy for driving virtually all of the processes associated with living cells. Maintaining an adequate supply of energy is an essential requirement for survival [1]. At a single cell level this means keeping ATP, the immediate source of energy, at a relatively high concentration - in the millimolar range in most eukaryotic cells. The concentration of ATP within most eukaryotic cells is kept at a remarkably constant level, despite wide fluctuations in the demand for ATP [2]. In order to achieve this, cells require systems to monitor changes in ATP levels, and to couple these changes to a transponder that leads to functional outputs to restore ATP levels. One such system that has been identified is the AMP-activated protein kinase (AMPK) and orthologues of AMPK are found in virtually all eukaryotes. A major function of AMPK is to monitor changes in the level of ATP and to couple this to phosphorylation of downstream substrates leading to an increase in the rate of ATP-producing pathways and/or a decrease in the rate of ATP-utilising pathways. Dysregulation of energy homeostasis is thought to be an important factor in driving changes in a wide range of human diseases, such as type 2 diabetes, obesity and cancer. The central role of AMPK in maintaining energy homeostasis has made it an attractive target for drugs aimed at preventing and/or treating metabolic diseases, including cancer [3-5]. In this review, I will focus on recent developments regarding the regulation of AMPK that directly impact on its therapeutic utility. I will also discuss some potential caveats arising from studies examining the role of AMPK in vivo using mouse models.

\section{AMPK Subunits}

Mammalian AMPK is a heterotrimeric complex [2, 6-8]. The $\alpha$ subunit encodes an N-terminal protein kinase domain (KD) linked to a $\mathrm{C}$-terminal regulatory domain. The $\mathrm{C}$-terminal region of the $\beta$ subunit acts as a scaffold, interacting with the $\gamma$ subunit and the $\mathrm{C}$-terminal region of the $\alpha$ subunit. The $\beta$ subunit also contains a region termed the carbohydrate binding module (CBM), sometimes also referred to as the glycogen binding domain (GDB). The $\gamma$ subunit contains 4 cystathionine- $\beta$-synthase (CBS) domains which are involved in nucleotide binding. 
In mammals there are 2 isoforms of the $\alpha$ and $\beta$ subunits and 3 isoforms of the $\gamma$ subunit (all isoforms encoded by distinct genes), which allows for the expression of 12 different AMPK complexes ( $\alpha 1 \beta 1 \gamma 1, \alpha 2 \beta 1 \gamma 1$ etc.). An important and largely unresolved issue is that of the biological relevance of the different isoform complexes (see Figure 1). Some clues have emerged from the identification of naturally occurring mutations in the $\gamma 2$ (human) and $\gamma 3$ (pig) isoforms. Mutations in the $\gamma$ isoforms lead to a gain-of-function of AMPK and so provide evidence of the effect of chronic AMPK activation in vivo. In humans, a number of dominantlyinherited mutations have been identified in $\gamma_{2}$ (PRKAG2) that lead to a cluster of severe cardiac abnormalities including left ventricular hypertrophy, glycogen accumulation and ventricular pre-excitation (Wolff-Parkinson-White Syndrome), often leading to sudden cardiac death [9-12]. In pigs, a mutation identified in $\gamma 3$ causes increased glycogen accumulation in skeletal muscle [13]. A striking feature of both the $\gamma 2$ and $\gamma 3$ mutations is the restricted nature of the resulting phenotypes. A plausible reason for this observation is related to the expression of the $\gamma$ isoforms. In humans, $\gamma 2$ is highly expressed in heart, whereas expression of $\gamma 3$ is almost exclusively restricted to fast twitch skeletal muscle $[13,14]$. The expression pattern of the different $\gamma$ isoforms may therefore provide a simple explanation for the phenotypes resulting from these naturally occurring mutations. An important issue that arises from this hypothesis is that in order to understand and interpret phenotypical changes it is critical to know the expression pattern of individual AMPK isoforms in the species being studied. If the goal is to develop therapeutic opportunities for treating human diseases, then it is essential that we understand the expression (and function) of the various AMPK complexes in human tissues. Of course, this is not a trivial undertaking and obtaining accurate and reliable data underlying human physiology at a molecular level is challenging. Animal models provide a widely used approach to gain insight into complex physiological processes, and whilst these provide valuable information, it is important to be aware of the potential limitations inherent in extrapolating from animal models to humans.

\section{Species specific roles}

In the case of AMPK, this is exemplified by two recent studies examining mouse models harbouring knock-in mutations of the Prkag2 gene encoding $\gamma 2[15,16]$. Three mouse lines were generated harbouring different mutations identified in patients with Wolff-ParkinsonWhite Syndrome: R302Q, N4881 and R531G. As well as observing differences in the phenotypes between the three mouse lines $[15,16]$, the phenotypes reported in the mouse models failed to recapitulate the symptoms associated with the human disease (see Table 1 ). How might these differences be reconciled? The hypothesis I would like to propose is that at least some of these differences could be accounted for by differences in tissue expression of $\gamma 2$ between species. In humans, $\gamma 2$ mRNA expression is highest in heart [14], whereas in the mouse the highest levels of expression are detected in the testis, kidney and brown and white adipose tissue, with relatively low expression in the heart [17]. Less is known about protein expression of $\gamma 2$ in either human or mouse tissues. In a recent study, however, it was reported that $\gamma 2$ protein was barely detectable in mouse heart, with much higher levels detected in liver, white adipose tissue and brain [18], reflecting reasonably well the previously reported mRNA expression profile in mouse. A possible explanation for the phenotypic differences could simply be due to differences in tissue expression of $\gamma 2$ between human and mouse. In humans, the evidence indicates that $\gamma 2$ is highly expressed in heart whereas in mouse cardiac expression is low. Conversely, in mouse $\gamma 2$ is highly expressed in brain, kidney and fat, tissues. 
These patterns of tissue expression fit well with the observed phenotypes in humans (with the naturally occurring mutations) and in the mouse knock-in models. Moreover, this idea would be consistent with the finding that transgenic mouse models in which $\gamma 2$ harbouring the same mutations as used in the knock-in models were overexpressed in the heart developed a cardiac phenotype that very closely resembled the human disease [19-21]. Table 1 compares the predominant phenotypes resulting from $\gamma 2$ mutations in humans with those obtained in the various mouse models.

\section{AMPK Regulation}

AMPK is activated by phosphorylation of threonine 172 (T172) within the activation segment of the KD of the $\alpha$ subunit [22]. In mammals, calcium/calmodulin dependent protein kinase kinase (CaMKK) $\beta$ and liver kinase B1 (LKB1) have been identified as the two upstream kinases in the cascade [23-26]. Phosphorylation of T172 increases AMPK activity by 2-3 orders of magnitude $[27,28]$. The rate of dephosphorylation of T172 is decreased by AMP/ADP [27, 29]. In addition, a number of small molecule direct activators of AMPK that bind between the KD and the CBM of the $\beta$ subunit have been identified (e.g. A769662, 991 and MT 63-78)[3, 5, 30] and these also protect against T172 dephosphorylation [5, 31, 32]. AMPK can be further activated allosterically by AMP binding to the $\gamma$ subunit, or by the small molecule activators [5] (see Figure 2). In each case, the degree of allosteric activation depends on the composition of the AMPK complex, and in the case of AMP is also influenced by the concentration of ATP present $[5,33,34]$. In cell free assays, AMP in the presence of 5 mM ATP (a concentration approximating the normal physiological range in mammalian cells) leads to approximately 8fold activation of $\gamma 1$-containing AMPK complexes, 6 -fold activation of $\gamma 2$-containing AMPK complexes but only 1.4-fold activation of $\gamma 3$-containing complexes [34]. The reason for the difference in allosteric response to AMP is unclear, but presumably is due to differences in the nucleotide binding sites within the $\gamma$ isoforms. Although the precise molecular mechanism for allosteric regulation by nucleotides remains unclear, evidence from a number of studies suggests that binding of AMP to site 3 mediates the effect. When AMP is bound at site $3, a$ region from the $\alpha$ subunit, termed the $\alpha$-hook $[5,35]$ or $\alpha$-RIM2 [36], interacts with site 3 and this interaction has been proposed to stabilise an active conformation of the kinase $[5,35]$. In contrast, if ATP is bound at site 3 , the $\alpha$-hook/ $\alpha$-RIM2 region is unable to interact as the $\gamma$ phosphate in ATP disrupts interactions between residues from $\gamma 1$ (e.g. arginine residue 70) and the $\alpha$-hook (e.g. glutamic acid 368) [5, 35]. This model provides an explanation of how information of nucleotide binding in the $\gamma$ subunit is propagated via $\alpha$-hook to the KD. The same model could also account for the transduction of signal for nucleotide binding to protection against dephosphorylation. However, it does not provide an explanation for why ADP binding at site 3 can lead to protection against dephosphorylation, but does not cause allosteric activation. Presumably subtle differences between the interaction of the $\alpha$-hook/ $\alpha$ RIM2 and site 3 in the presence of ADP versus AMP account for the lack of allosteric effect when ADP occupies site 3.

A number of studies have reported that nucleotides can promote T172 phosphorylation, although this aspect of regulation remains controversial. One study reported that both AMP and ADP promote T172 phosphorylation by CaMKK $\beta$ [37], whereas another study reported activation by AMP, but not ADP, via LKB1, but not CaMKK $\beta$ [38]. The molecular mechanism for these effects remains unclear, although a separate study reported that AMP promotes interaction between AMPK, LKB1 and axin, which itself interacts with LAMTOR1 on lysosomes 
[39]. By promoting the interaction between AMPK and LKB1, axin could provide a mechanism for increased T172 phosphorylation by AMP. Very recently, a study showing that the axinAMPK-LKB1 interaction is required for activation of AMPK by metformin in liver in vivo, as well as in cell based studies in HEK293 cells and mouse embryonic fibroblasts, was published [40]. In this study, metformin was reported to act directly on the V-ATPase, which promoted translocation of an axin-LKB1 complex to the lysosomal surface, ultimately leading to activation of AMPK. These findings open up new and intriguing avenues for our understanding of AMPK regulation, particularly by metformin. A rise in intracellular calcium also leads to increased T172 phosphorylation through activation of CaMKK $\beta[24,25,41,42]$, providing another signalling pathway for modulation of AMPK.

\section{Pharmacological AMPK activators}

As is the case with AMP, the degree of allosteric activation by 991, depends on the isoform composition of the AMPK complex, ranging from about 3-fold for $\alpha 1 \beta 2 \gamma 1$ to over 10 -fold for $\alpha 2 \beta 1 \gamma 1$ [5]. Moreover, where it has been reported, the drugs that have been identified to date bind significantly tighter to AMPK complexes containing the $\beta 1$ isoform relative to $\beta 2$. An important point to note here, however, is that although there is clearly isoform selectivity between binding to $\beta 1$ - and $\beta 2$-containing AMPK complexes, in some cases e.g. 991, $\beta 2$ complexes bind with an affinity that is sufficiently high to be readily detectable in cell-based assays [5]. This is an important consideration because previous studies using A769662, the first direct small molecule AMPK activator to be described [3], led to the suggestion that only $\beta 1$-containing complexes are targets for activation [43]. With the identification of more potent AMPK activators it is now clear that this is not the case [44]. However, the finding that drugs have different binding affinities between $\beta 1$ and $\beta 2$ complexes opens up the possibility of designing isoform-selective AMPK activators. Importantly, exploiting differences in isoform-selectivity may provide beneficial therapeutic opportunities in the future. In a recent study, an AMPK activator, PF-06409577, was identified that binds at least 1000-fold tighter to $\beta 1$-complexes compared to $\beta 2$-complexes [45], suggesting that this type of strategy is feasible.

The structures of AMPK bound to several different small molecule activators have been reported and they all reveal a similar mode of binding $[5,45,46]$. A single binding pocket is formed by an interaction between the small lobe of the KD and the CBM of the $\beta$ subunit. Several interesting features emerge from the structural studies. Firstly, phosphorylated serine 108 (pS108) in the $\beta 1$ subunit forms a number of electrostatic interactions with residues from the $\alpha$ and $\beta$ subunit, and mutation of S108 to alanine significantly weakens binding of A769662 and 991 [5]. This finding supports earlier biochemical studies that showed an important role for pS108 in activation of AMPK by A769662 [32]. S108 is an autophosphorylation site $[47,48]$, and is phosphorylated in AMPK complexes expressed in bacteria (in the complete absence of T172 phosphorylation [49]) so it is not clear whether S108 phosphorylation of $\beta 1$ plays a role in AMPK regulation in vivo. Secondly, an $\alpha$ helix immediately C-terminal to the CBM (termed the C-interacting helix) interacts with the $\alpha \mathrm{C}$ helix of the KD. The sequence of the $C$-interacting helix is highly conserved in $\beta 1$ and $\beta 2$, and across a broad range of species [5]. Similarly, the sequence of the $\alpha \mathrm{C}$ helix is highly conserved between $\alpha 1$ and $\alpha 2$, and across species. The high level of conservation suggests that the interaction between the two helices may play an important functional role. By analogy with other kinases [50], it is possible that binding of the activator facilitates interaction of the C- 
interacting helix with the $\alpha \mathrm{C}$ helix which in turn promotes an active conformation of the kinase. Consistent with this hypothesis mutation of leucine residue 166 in the C-interacting helix dramatically reduces allosteric activation of AMPK by 991 [5]. A third exciting feature emerging from the identification of the binding pocket is the possibility that a natural ligand for the site may exist. Although the existence of this ligand is purely speculative if such a molecule was identified it could offer new insight into the regulation of AMPK.

\section{Role of AMPK phosphorylation}

A recent study examined the requirement for T172 and S108 phosphorylation on AMPK activity [49]. In the absence of T172 phosphorylation, A769662 activated AMPK to a level similar to that of AMPK phosphorylated on T172. Phosphorylation of S108 on $\beta 1$ was required for optimal activation of the non-T172 phosphorylated AMPK by A769662, and mutation of S108 to an alanine significantly reduced the ability of A769662 to stimulate AMPK. However, the presence of both AMP and A769662 was sufficient to override the requirement for both T172 and S108 phosphorylation. These findings raise the intriguing possibility that AMPK activation can occur solely by allosteric activation and in the complete absence of T172 and S108 phosphorylation [49]. Does this mean that phosphorylation of T172 (or S108 in $\beta 1$ ) is not relevant for AMPK activity or regulation? From an evolutionary angle it is difficult to imagine that a complex regulatory system has evolved and been maintained if it plays no role. Furthermore, there is overwhelming evidence that activation of AMPK in cells and in vivo is correlated with an increase in T172 phosphorylation. However, that is not to say that the allosteric activation of AMPK is not important, but that in most situations this is accompanied by increased T172 phosphorylation (and presumably by increased S108 phosphorylation, although this has not been well studied to date). As has been raised previously [49], one situation where a purely allosteric activation (i.e. in the absence of T172 and S108 phosphorylation) could be important and potentially exploited would be through a pharmacological approach. In many cancers LKB1 activity is lost which leads to reduced T172 phosphorylation. In this situation, it might be possible to activate AMPK by treating with a drug that binds in the $K D / C B M$ pocket. In this regard it is worth reiterating that autophosphorylation of S108 can occur in the absence of T172 phosphorylation, so drug binding to $\beta 1$-complexes would occur with high affinity. At present it is not clear whether a similar type of regulation applies to $\beta 2$-complexes. However, some drugs, e.g. 991, bind with reasonably high affinity to $\beta 2$-containing AMPK complexes suggesting that it should be possible to target $\beta 2$-complexes in vivo, if the mechanism is conserved for both $\beta$ isoforms. If such a mechanism could be exploited it would open up an exciting new therapeutic opportunity.

\section{Conclusions and Perspectives}

AMPK plays an important role in maintaining energy homeostasis in eukaryotic cells. In multicellular organisms, the role of AMPK has been adapted to play a role in integrating energy metabolism at an organismal level. There has been a significant development over the last few years in identifying small molecule direct AMPK activators, and we now understand the mechanism by which a major class of these drugs work to activate the kinase. A key challenge for the future is to translate findings from cell based studies and animal models through to human physiology/pathology in order to identify the best approaches for maximising the therapeutic potential of targeting AMPK. 


\section{Acknowledgements}

Studies in the author's laboratory are funded by the Medical Research Council and a BBSRC/CASE PhD studentship award in collaboration with AstraZeneca. I would like to thank members of my group for many helpful discussions whilst preparing this manuscript.

\section{References and recommended reading}

Papers of particular interest, published within the period of review, have been highlighted as: * of special interest, ${ }^{* *}$ of outstanding interest

1 Boyer, P. D., Chance, B., Ernster, L., Mitchell, P., Racker, E. and Slater, E. C. (1977) Oxidative phosphorylation and photophosphorylation. Annu. Rev. Biochem. 46, 955-1026

2 Carling, D., Thornton, C., Woods, A. and Sanders, M. J. (2012) AMP-activated protein kinase: new regulation, new roles? Biochem J. 445, 11-27

3 Cool, B., Zinker, B., Chiou, W., Kifle, L., Cao, N., Perham, M., Dickinson, R., Adler, A., Gagne, G., Iyengar, R., Zhao, G., Marsh, K., Kym, P., Jung, P., Camp, H. S. and Frevert, E. (2006) Identification and characterization of a small molecule AMPK activator that treats key components of type 2 diabetes and the metabolic syndrome. Cell Metab. 3, 403-416

4 Giordanetto, F. and Karis, D. (2012) Direct AMP-activated protein kinase activators: a review of evidence from the patent literature. Exprt Opin. Ther. Pat. 22, 1467-1477

5 Xiao, B., Sanders, M. J., Carmena, D., Bright, N. J., Haire, L. F., Underwood, E., Patel, B. R., Heath, R. B., Walker, P. A., Hallen, S., Giordanetto, F., Martin, S. R., Carling, D. and Gamblin, S. J. (2013) Structural basis of AMPK regulation by small molecule activators. Nat. Commun. 4, 3017

6 Carling, D., Mayer, F. V., Sanders, M. J. and Gamblin, S. J. (2011) AMP-activated protein kinase: nature's energy sensor. Nat. Chem. Biol. 7, 512-518

7 Hardie, D. G., Schaffer, B. E. and Brunet, A. (2016) AMPK: An Energy-Sensing Pathway with Multiple Inputs and Outputs. Trends Cell Biol. 26, 190-201

8 Steinberg, G. R. and Kemp, B. E. (2009) AMPK in health and disease. Physiol. Rev. 89, 1025-1078

9 Arad, M., Benson, D. W., Perez-Atayde, A. R., McKenna, W. J., Sparks, E. A., Kanter, R. J., McGarry, K., Seidman, J. G. and Seidman, C. E. (2002) Constitutively active AMP kinase mutations cause glycogen storage disease mimicking hypertrophic cardiomyopathy. J. Clin. Invest. 109, 357-362

10 Blair, E., Redwood, C., Ashrafian, H., Ostman-Smith, I. and Watkins, H. (2001) Mutations in the g2 subunit of AMP-activated protein kinase cause familial hypertrophic cardiomyopathy: evidence for the central role of energy compromise in disease pathogenesis. Hum. Mol. Genet. 10, 1215-1220

11 Gollob, M. H., Green, M. S., Tang, A. S. L., Gollob, T., Karibe, A., Hassan, A., Ahmad, F., Lozado, R., Shah, G., Fananapazir, L., Bachiniski, L. L., Tapscott, T., Gonzales, O., Begley, D., Mohiddin, S. and Roberts, R. (2001) Identification of a gene responsible for familial WolffParkinson-White syndrome. New Eng. J. Med. 344, 1823-1831

12 Gollob, M. H., Seger, J. J., Gollob, T. N., Tapscott, T., Gonzales, O., Bachiniski, L. and Roberts, R. (2001) Novel PRKAG2 mutation responsible for the genetic syndrome of ventricular preexcitation and conduction system disease with childhood onset and absence of cardiac hypertrophy. Circulation. 104, 3030-3033

13 Milan, D., Jeon, J. T., Looft, C., Amarger, V., Robic, A., Thelander, M., Rogel-Gaillard, C., Paul, S., lannuccelli, N., Rask, L., Ronne, H., Lundström, K., Reinsch, N., Gellin, J., Kalm, E., 
Le Roy, P., Chardon, P. and Andersson, L. (2000) A mutation in PRKAG3 associated with excess glycogen content in pig skeletal muscle. Science. 288, 1248-1251

14 Cheung, P. C. F., Salt, I. P., Davies, S. P., Hardie, D. G. and Carling, D. (2000) Characterization of AMP-activated protein kinase g-subunit isoforms and their role in AMP binding. Biochem. J. 346, 659-669

**15 Yavari, A., Stocker, C. J., Ghaffari, S., Wargent, E. T., Steeples, V., Czibik, G., Pinter, K., Bellahcene, M., Woods, A., Martinez de Morentin, P. B., Cansell, C., Lam, B. Y., Chuster, A., Petkevicius, K., Nguyen-Tu, M. S., Martinez-Sanchez, A., Pullen, T. J., Oliver, P. L., Stockenhuber, A., Nguyen, C., Lazdam, M., O'Dowd, J. F., Harikumar, P., Toth, M., Beall, C., Kyriakou, T., Parnis, J., Sarma, D., Katritsis, G., Wortmann, D. D., Harper, A. R., Brown, L. A., Willows, R., Gandra, S., Poncio, V., de Oliveira Figueiredo, M. J., Qi, N. R., Peirson, S. N., McCrimmon, R. J., Gereben, B., Tretter, L., Fekete, C., Redwood, C., Yeo, G. S., Heisler, L. K., Rutter, G. A., Smith, M. A., Withers, D. J., Carling, D., Sternick, E. B., Arch, J. R., Cawthorne, M. A., Watkins, H. and Ashrafian, H. (2016) Chronic Activation of gamma2 AMPK Induces Obesity and Reduces beta Cell Function. Cell Metab. 23, 821-836

This study reports that mice expressing $\gamma 2$ harbouring $R 302 Q$ mutation are hyperphagic and develop adult-onset obesity and impaired glucose homeostasis.

**16 Yang, X., Mudgett, J., Bou-About, G., Champy, M. F., Jacobs, H., Monassier, L., Pavlovic, G., Sorg, T., Herault, Y., Petit-Demouliere, B., Lu, K., Feng, W., Wang, H., Ma, L. J., Askew, R., Erion, M. D., Kelley, D. E., Myers, R. W., Li, C. and Guan, H. P. (2016) Physiological expression of AMPKg2RG mutation causes Wolff-Parkinson-White Syndrome and induces kidnety injury in mice. J. Biol. Chem. in press

Describes the phenotype of two mouse lines (expressing $\gamma 2$ with either N488I or R531G mutation). Both lines are protected against high fat diet-induced obesity. A very mild cardiac phenotype is reported (much less severe than the human disease) and the R531G line develops kidney cysts and impaired kidney function.

17 Mahlapuu, M., Johansson, C., Lindgren, K., Hjalm, G., Barnes, B. R., Krook, A., Zierath, J. R., Andersson, L. and Marklund, S. (2004) Expression profiling of the gamma-subunit isoforms of AMP-activated protein kinase suggests a major role for gamma3 in white skeletal muscle. Am J Physiol Endocrinol Metab. 286, E194-200

18 Bultot, L., Jensen, T. E., Lai, Y. C., Madsen, A. L., Collodet, C., Kviklyte, S., Deak, M., Yavari, A., Foretz, M., Ghaffar, i. S., Bellahcene, M., Ashrafian, H., Rider, M. H., Richter, E. A. and Sakamoto, K. (2016) Benzimidazole derivative small-molecule 991 enhances AMPK activity

and glucose uptake induced by AICAR or contraction in skeletal muscle. Am. J. Physiol. 311, E706-E719

19 Arad, M., Moskowitz, I. P., Patel, V. V., Ahmad, F., Perez-Atayde, A. R., Sawyer, D. B., Walter, M., Li, G. H., Burgon, P. G., Maguire, C. T., Stapleton, D., Schmitt, J. P., Guo, X. X., Pizard, A., Kupershmidt, S., Roden, D. M., Berul, C. I., Seidman, C. E. and Seidman, J. G. (2003) Transgenic Mice Overexpressing Mutant PRKAG2 Define the Cause of Wolff-Parkinson-White Syndrome in Glycogen

Storage Cardiomyopathy. Circulation. 107, 2850-2856

20 Davies, J. K., Wells, D. J., Liu, K., Whitrow, H. R., Daniel, T. D., Grignani, R., Lygate, C. A., Schneider, J. E., Noel, G., Watkins, H. and Carling, D. (2006) Characterization of the role of gamma2 R531G mutation in AMP-activated protein kinase in cardiac hypertrophy and WolffParkinson-White syndrome. Am J Physiol Heart Circ Physiol. 290, H1942-1951 
21 Sidhu, J. S., Rajawat, Y. S., Rami, T. G., Gollob, M. H., Wang, Z., Yuan, R., Marian, A. J., DeMayo, F. J., Weilbacher, D., Taffet, G. E., Davies, J. K., Carling, D., Khoury, D. S. and Roberts, R. (2005) Transgenic mouse model of ventricular preexcitation and atrioventricular reentrant tachycardia induced by an AMP-activated protein kinase loss-of-function mutation responsible for Wolff-Parkinson-White syndrome. Circulation. 111, 21-29

22 Hawley, S. A., Davison, M., Woods, A., Davies, S. P., Beri, R. K., Carling, D. and Hardie, D. G. (1996) Characterization of the AMP-activated protein kinase kinase from rat liver and identification of threonine 172 as the major site at which it phosphorylates AMP-activated protein kinase. J Biol Chem. 271, 27879-27887

23 Hawley, S. A., Boudeau, J., Reid, J. L., Mustard, K. J., Udd, L., Makela, T. P., Alessi, D. R. and Hardie, D. G. (2003) Complexes between the LKB1 tumor suppressor, STRAD alpha/beta and MO25 alpha/beta are upstream kinases in the AMP-activated protein kinase cascade. J. Biol. 2, 28

24 Hawley, S. A., Pan, D. A., Mustard, K. J., Ross, L., Bain, J., Edelman, A. M., Frenguelli, B. G. and Hardie, D. G. (2005) Calmodulin-dependent protein kinase kinase-beta is an alternative upstream kinase for AMP-activated protein kinase. Cell Metab. 2, 9-19

25 Woods, A., Dickerson, K., Heath, R., Hong, S. P., Momcilovic, M., Johnstone, S. R., Carlson, M. and Carling, D. (2005) Ca2+/calmodulin-dependent protein kinase kinase-beta acts upstream of AMP-activated protein kinase in mammalian cells. Cell Metab. 2, 21-33

26 Woods, A., Johnstone, S. R., Dickerson, K., Leiper, F. C., Fryer, L. G., Neumann, D., Schlattner, U., Wallimann, T., Carlson, M. and Carling, D. (2003) LKB1 is the upstream kinase in the AMP-activated protein kinase cascade. Curr. Biol. 13, 2004-2008

27 Sanders, M. J., Grondin, P. O., Hegarty, B. D., Snowden, M. A. and Carling, D. (2007) Investigating the mechanism for AMP activation of the AMP-activated protein kinase cascade. Biochem. J. 403, 139-148

28 Suter, M., Riek, U., Tuerk, R., Schlattner, U., Wallimann, T. and Neumann, D. (2006) Dissecting the role of AMP for allosteric stimulation, activation and deactivation of AMPactivated protein kinase. J. Biol. Chem. 281, 32207-32216

29 Davies, S. P., Helps, N. R., Cohen, P. T. and Hardie, D. G. (1995) 5'-AMP inhibits dephosphorylation, as well as promoting phosphorylation, of the AMP-activated protein kinase. Studies using bacterially expressed human protein phosphatase- $2 \mathrm{C}$ alpha and native bovine protein phosphatase-2AC. FEBS Lett. 377, 421-425

30 Zadra, G., Photopoulos, C., Tyekucheva, S., Heidari, P., Weng, Q. P., Fedele, G., Liu, H., Scaglia, N., Priolo, C., Sicinska, E., Mahmood, U., Signoretti, S., Birnberg, N. and Loda, M. (2014) A novel direct activator of AMPK inhibits prostate cancer growth by blocking lipogenesis. EMBO Mol. Med. 6, 519-538

31 Goransson, O., McBride, A., Hawley, S. A., Ross, F. A., Shpiro, N., Foretz, M., Viollet, B., Hardie, D. G. and Sakamoto, K. (2007) Mechanism of action of A-769662, a valuable tool for activation of AMP-activated protein kinase. J. Biol. Chem. 282, 32549-32560

32 Sanders, M. J., Ali, Z. S., Hegarty, B. D., Heath, R., Snowden, M. A. and Carling, D. (2007) Defining the mechanism of activation of AMP-activated protein kinase by the small molecule A-769662, a member of the thienopyridone family. J. Biol. Chem. 282, 32539-32548

*33 Rajamohan, F., Reyes, A. R., Frisbie, R. K., Hoth, L. R., Sahasrabudhe, P., Magyar, R., Landro, J. A., Withka, J. M., Caspers, N. L., Calabrese, M. F., Ward, J. and Kurumbail, R. G. (2016) Probing the enzyme kinetics, allosteric modulation and activation of $\alpha 1$ and $\alpha 2$-subunit-containing AMP-activated protein kinase (AMPK) heterotrimeric complexes by pharmacological and physiological activators. Biochem. J. 473, 581-592 
Reports the effects of different AMPK subunit isoforms on activation of AMPK complexes by nucleotides and A769662.

*34 Ross, F. A., Jensen, T. E. and Hardie, D. G. (2016) Differential regulation by AMP and ADP of AMPK complexes containing different gamma subunit isoforms. Biochem J. 473, 189199

Reports the effects of different $\gamma$ subunit isoforms on AMPK regulation by nucleotides. The findings suggest that the $\gamma$ isoforms could play a physiological role in regulating AMPK activity. 35 Xiao, B., Sanders, M. J., Underwood, E., Heath, R., Mayer, F., Carmena, D. J., Jing, C., Walker, P. A., Eccleston, J. E., Haire, L. F., Martin, S. R., Carling, D. and Gamblin, S. J. (2011) Structure of mammalian AMPK and its regulation by ADP. Nature. 472, 230-233

36 Xin, F. J., Wang, J., Zhao, R. Q., Wang, Z. X. and Wu, J. W. (2013) Coordinated regulation of AMPK activity by multiple elements in the a subunit. Cell Res. . 23, 1237-1240

37 Oakhill, J. S., Stell, R., Chen, Z. P., Scott, J. W., Ling, N., Tam, S. and Kemp, B. E. (2011) AMPK is a direct adenylate charge-regulated protein kinase. Science. 332, 1433-1435

38 Gowans, G. J., Hawley, S. A., Ross, F. A. and Hardie, D. G. (2013) AMP is a true physiological regulator of AMP-activated protein kinase by both allosteric activation and enhancing net phosphorylation. Cell Metab. 18, 556-566

39 Zhang, Y. L., Guo, H., Zhang, C. S., Lin, S. Y., Yin, Z., Peng, Y., Luo, H., Shi, Y., Lian, G., Zhang, C., Li, M., Ye, Z., Ye, J., Han, J., Li, P., Wu, J. W. and Lin, S. C. (2013) AMP as a low-energy charge signal autonomously initiates assembly of AXIN-AMPK-LKB1 complex for AMPK activation. Cell Metab. 18, 546-555

**40 Zhang, C. S., Li, M., Ma, T., Zong, Y., Cui, J., Feng, J. W., Wu, Y. Q., Lin, S. Y. and Lin, S. C. (2016) Metformin activates AMPK through the lysosomal pathway. Cell Metab. 24, 521522

A short paper that reports that axin is required for the activation of AMPK in liver by metformin in vivo.

41 Hurley, R. L., Anderson, K. A., Franzone, J. M., Kemp, B. E., Means, A. R. and Witters, L. A. (2005) The Ca2+/calmodulin-dependent protein kinase kinases are AMP-activated protein kinase kinases. J. Biol. Chem. 280, 29060-29066

42 Stahmann, N., Woods, A., Carling, D. and Heller, R. (2006) Thrombin activates AMPactivated protein kinase in endothelial cells via a pathway involving $\mathrm{Ca} 2+/$ calmodulindependent protein kinase kinase beta. Mol. Cell. Biol. 26, 5933-5945

43 Scott, J. W., van Denderen, B. J., Jorgensen, S. B., Honeyman, J. E., Steinberg, G. R., Oakhill, J. S., Iseli, T. J., Koay, A., Gooley, P. R., Stapleton, D. and Kemp, B. E. (2008) Thienopyridone drugs are selective activators of AMP-activated protin kinase beta1containing complexes. Chem. Biol. 15, 1220-1230

44 Lai, Y. C., Kviklyte, S., Vertommen, D., Lantier, L., Foretz, M., Viollet, B., Hallén, S. and Rider, M. H. (2014) A small-molecule benzimidazole derivative that potently activates AMPK to increase glucose transport in skeletal muscle: comparison with effects of contraction and other AMPK activators. Biochem. J. 460, 363-375

*45 Cameron, K. O., Kung, D. W., Kalgutkar, A. S., Kurumbail, R. G., Miller, R., Salatto, C. T., Ward, J., Withka, J. M., Bhattacharya, S. K., Boehm, M., Borzilleri, K. A., Brown, J. A., Calabrese, M., Caspers, N. L., Cokorinos, E., Conn, E. L., Dowling, M. S., Edmonds, D. J., Eng, H., Fernando, D. P., Frisbie, R., Hepworth, D., Landro, J., Mao, Y., Rajamohan, F., Reyes, A. R., Rose, C. R., Ryder, T., Shavnya, A., Smith, A. C., Tu, M., Wolford, A. C. and Xiao, J. (2016) Discovery and preclinical characterization of 6-chloro-5-[4-(1-hydroxycyclobutyl)phenyl]-1H-indole-3carboxylic acid (PF-06409577), a direct activator of adenosine monophosphate-activated 
protein kinase (AMPK), for the potential treatment of diabetic nephropathy. J. Med. Chem. $59,8068-8081$

Identifies a novel AMPK activator that shows marked selectivity for $\beta 1$-containing AMPK complexes.

46 Calabrese, M. F., Rajamohan, F., Harris, M. S., Caspers, N. L., Magyar, R., Withka, J. M., Wang, H., Borzilleri, K. A., Sahasrabudhe, P. V., Hoth, L. R., Geoghegan, K. F., Han, S., Brown, J., Subashi, T. A., Reyes, A. R., Frisbie, R. K., Ward, J., Miller, R. A., Landro, J. A., Londregan, A. T., Carpino, P. A., Cabral, S., Smith, A. C., Conn, E. L., Cameron, K. O., Qiu, X. and Kurumbail, R. G. (2014) Structural basis for AMPK activation: natural and synthetic ligands regulate kinase activity from opposite poles by different molecular mechanisms. Structure. 22, 1161-1172

47 Mitchelhill, K., Michell, B., House, C., Stapleton, D., Dyck, J., Gamble, J., Ullrich, C., LA., W. and Kemp, B. (1997) Posttranslational modifications of the 5'-AMP-activated protein kinase b1 subunit. J.Biol. Chem. 272, 24475-24479

48 Woods, A., Vertommen, D., Neumann, D., Turk, R., Bayliss, J., Schlattner, U., Wallimann, T., Carling, D. and Rider, M. H. (2003) Identification of phosphorylation sites in AMP-activated protein kinase (AMPK) for upstream AMPK kinases and study of their roles by site-directed mutagenesis. J. Biol. Chem. 278, 28434-28442

49 Scott, J. W., Ling, N., Issa, S. M., Dite, T. A., O'Brien, M. T., Chen, Z. P., Galic, S., Langendorf, C. G., Steinberg, G. R., Kemp, B. E. and Oakhill, J. S. (2014) Small molecule drug A-769662 and AMP synergistically activate naive AMPK independent

of upstream kinase signaling. Chem. Biol. 21, 619-627

50 Endicott, J. A., Noble, M. E. and Johnson, L. N. (2012) The structural basis for control of eukaryotic protein kinases. . Annu. Rev. Biochem. 81, 587-613

51 Murphy, R. T., Mogensen, J., McGarry, K., Bahl, A., Evans, A., Osman, E., Syrris, P., Gorman, G., Farrell, M., Holton, J. L., Hanna, M. G., Hughes, S., Elliott, P. M., Macrae, C. A. and McKenna, W. J. (2005) Adenosine monophosphate-activated protein kinase disease mimicks hypertrophic cardiomyopathy and Wolff-Parkinson-White syndrome: natural history. J Am Coll Cardiol. 45, 922-930 
Table 1. Mutations in AMPK $\gamma$ 2: human versus mouse models

\begin{tabular}{|c|c|c|c|}
\hline $\begin{array}{l}\text { PRKAG2 } \\
\text { Mutation } \\
\text { (Mouse) }\end{array}$ & $\begin{array}{l}\text { Human Disease } \\
\text { Phenotype }\end{array}$ & $\begin{array}{l}\text { Mouse Knock-In Model } \\
\text { Phenotype }\end{array}$ & $\begin{array}{l}\text { Mouse Transgenic } \\
\text { Overexpression Model } \\
\text { Phenotype }\end{array}$ \\
\hline $\begin{array}{l}\text { R302Q } \\
\text { (R299Q) }\end{array}$ & $\begin{array}{l}\text { Pre-excitation, AV } \\
\text { block, sinus } \\
\text { bradycardia, variable } \\
\text { LVH with variable } \\
\text { cardiac glycogen } \\
\text { accumulation, reports } \\
\text { of sudden cardiac } \\
\text { death, increased } \\
\text { adiposity and reduced } \\
\beta \text { cell function }([9,11 \text {, } \\
15])\end{array}$ & $\begin{array}{l}\text { Heart phenotype not } \\
\text { reported, hyperphagia } \\
\text { leading to adult-onset } \\
\text { obesity, impaired insulin } \\
\text { secretion }([15])^{2}\end{array}$ & $\begin{array}{l}\text { Pre-excitation, AV } \\
\text { block, LVH, dramatic } \\
\text { increase in heart } \\
\text { weight (more than } \\
\text { double wild type } \\
\text { weight), marked } \\
\text { cardiac glycogen } \\
\text { accumulation ([21]) }\end{array}$ \\
\hline $\begin{array}{l}\text { N488I } \\
\text { (N485I) }\end{array}$ & $\begin{array}{l}\text { Pre-excitation, } \\
\text { moderate LVH with } \\
\text { cardiac glycogen } \\
\text { accumulation present } \\
([9,51])\end{array}$ & $\begin{array}{l}\text { Sinus bradycardia, very } \\
\text { moderate increase in } \\
\text { heart weight, no glycogen } \\
\text { accumulation, resistance } \\
\text { to diet-induced obesity } \\
([16])^{3}\end{array}$ & $\begin{array}{l}\text { Pre-excitation, LVH, } \\
\text { dramatic increase in } \\
\text { heart weight (more } \\
\text { than double wild type } \\
\text { weight), marked } \\
\text { cardiac glycogen } \\
\text { accumulation, sinus } \\
\text { bradycardia, sudden } \\
\text { cardiac death ([19]) }\end{array}$ \\
\hline $\begin{array}{l}\text { R531G } \\
\text { (R528G) }\end{array}$ & $\begin{array}{l}\text { Early onset disease, } \\
\text { pre-excitation, no LVH } \\
\text { or cardiac glycogen } \\
\text { accumulation reported } \\
\text { ([12]) }\end{array}$ & $\begin{array}{l}\text { Sinus bradycardia, } \\
\text { shortened PR interval, } \\
\text { very moderate increase in } \\
\text { heart weight ( } 10 \% \\
\text { relative to wild type), } \\
\text { some glycogen } \\
\text { accumulation, resistance } \\
\text { to diet-induced obesity, } \\
\text { kidney cysts and } \\
\text { moderate impairment of } \\
\text { kidney function, } \\
\text { exacerbated on a high fat } \\
\text { diet }([16])^{3}\end{array}$ & $\begin{array}{l}\text { Pre-excitation, LVH, } \\
\text { dramatic increase in } \\
\text { heart weight (more } \\
\text { than double wild type } \\
\text { weight), marked } \\
\text { cardiac glycogen } \\
\text { accumulation, sudden } \\
\text { cardiac death ([20]) }\end{array}$ \\
\hline
\end{tabular}

${ }^{1}$ The transgenic models listed here all used $\alpha$-myosin heavy chain promoter to drive cardiacspecific expression of the transgene

${ }^{2}$ In this study, the effects observed were more marked in males versus female mice, and in homozygous versus heterozygous mice

${ }^{3}$ It was not reported whether heterozygous or homozygous mice were used in this study.

In each case, the references from which the data was obtained are shown.

$\mathrm{LVH}$, left ventricular hypertrophy; AV, atrioventricular. 


\section{Figure Legends}

Figure 1. Multi-faceted control and function of AMPK.

Mammalian AMPK exists as 12 different complexes composed of different subunit isoforms. As well as having tissue-specific expression patterns, it is possible that the different complexes are localised in different intracellular compartments. AMPK is activated by different signals (calcium, decreased ATP:ADP and ATP:AMP ratios, and a wide range of natural and synthetic small molecules), and these signals have different effects on AMPK depending on the isoform composition of the complex. Once activated, AMPK phosphorylates multiple downstream targets, some of which will be cell type-specific. It is also possible that phosphorylation of downstream targets will depend on the isoform composition of the AMPK complex.

\section{Figure 2. Regulation of AMPK}

AMPK is activated by phosphorylation of T172. Calcium activates CaMKK $\beta$ to increase T172 phosphorylation (phosphorylation sites depicted by red circles). AMP has been reported to increase phosphorylation of T172 by LKB1 by promoting the interaction of LKB1 and AMPK via axin, and ADP was shown to increase T172 phosphorylation by CaMKK $\beta$. The precise mechanism by which AMP or ADP promote T172 phosphorylation remains unclear, and so these signalling events are marked by dashed arrows to indicate this lack of understanding. The rate of dephosphorylation of T172 is reduced by a fall in the concentration of ATP relative to ADP and AMP, and by small molecule activators such as 991 and A769662. Phosphorylation of $\mathrm{S} 108$ in $\beta 1$ increases the binding affinity of these drugs. S108 in $\beta 1$ can be autophosphorylated even in the absence of T172 phosphorylation. AMP and drugs further allosterically activate AMPK. Allosteric activation by drugs appears to cause a significant activation of non-T172 phosphorylated AMPK, providing a potential therapeutic opportunity for activating AMPK without T172 phosphorylation. 


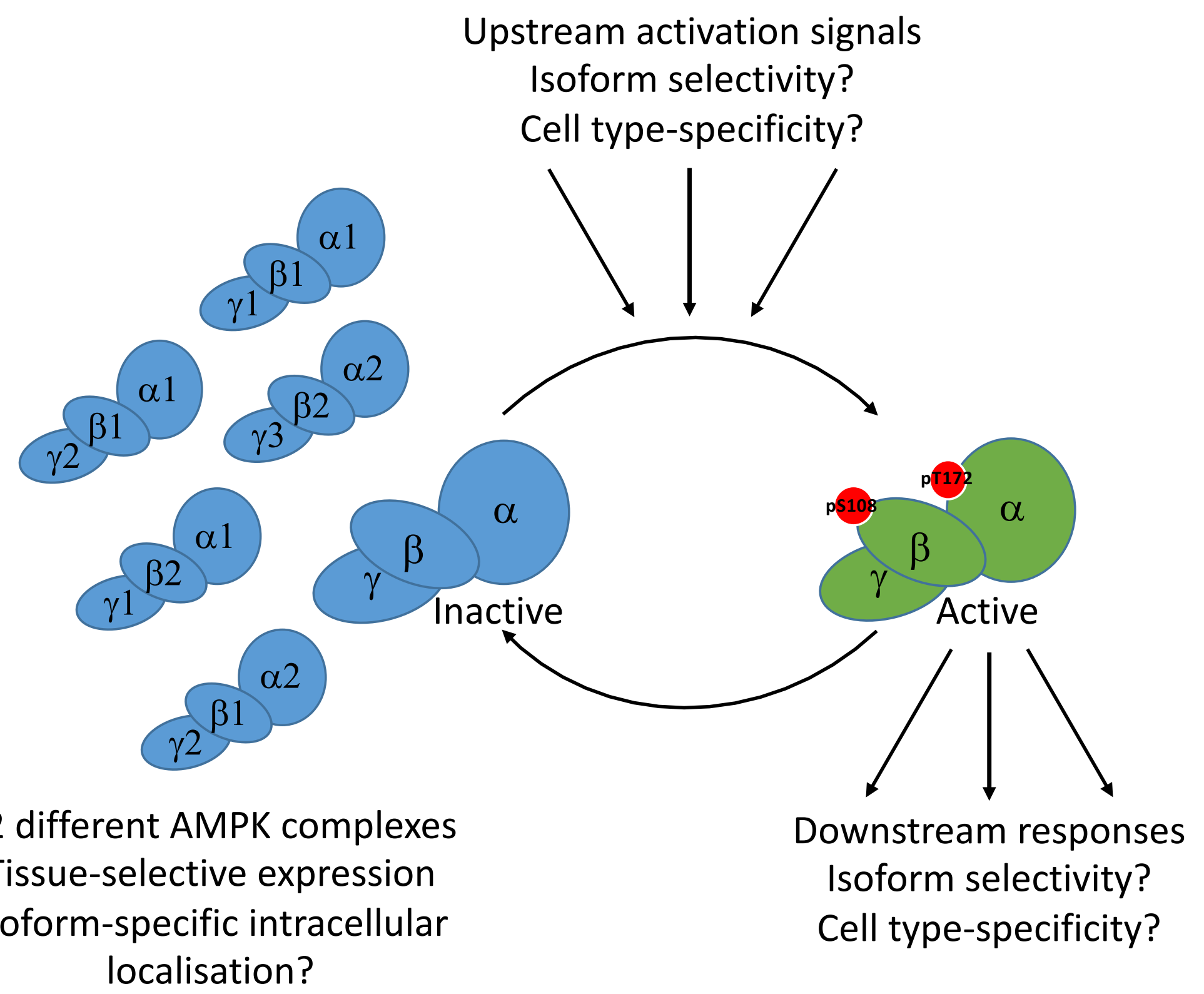


Drugs e.g. 991

A769662
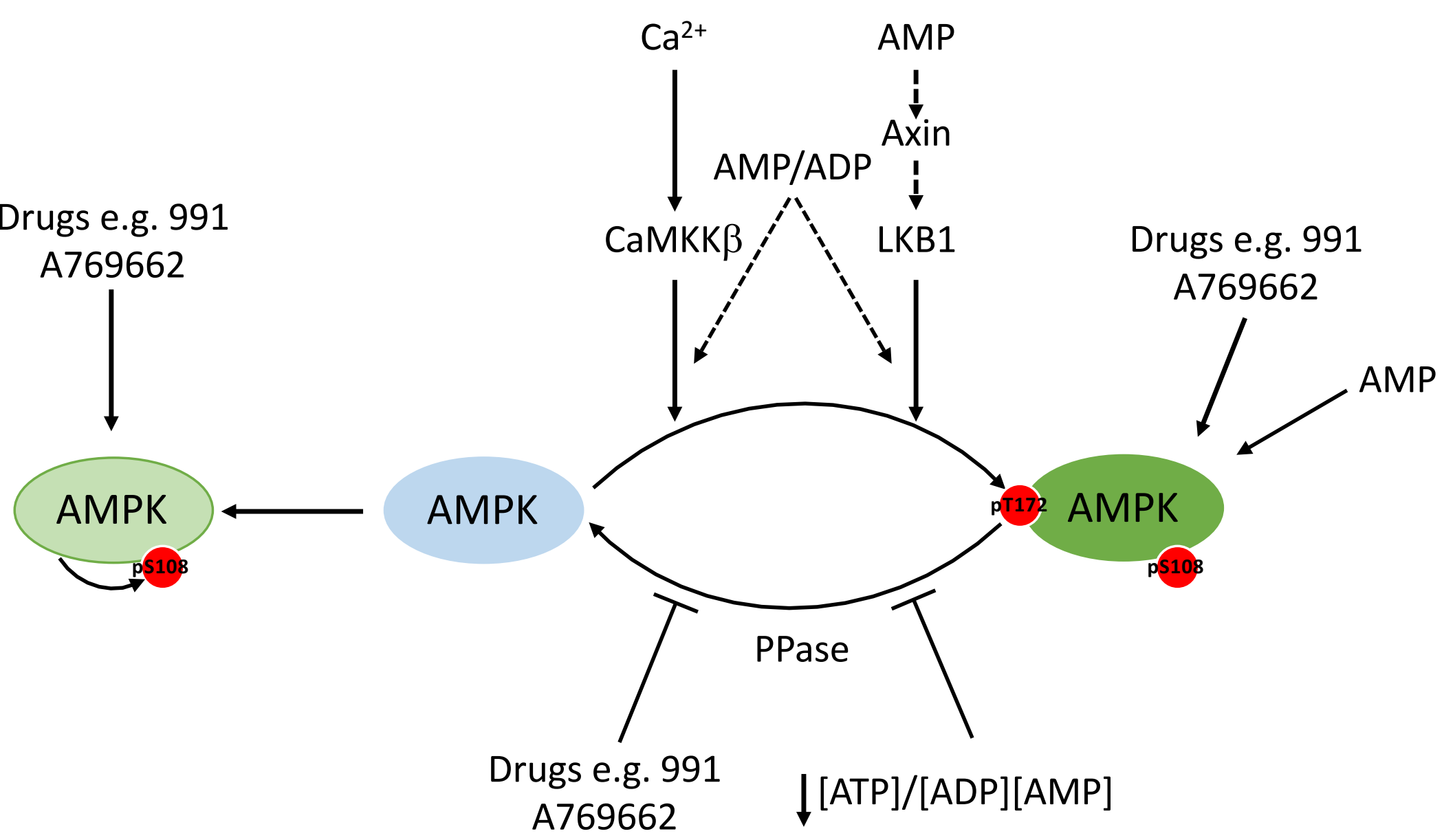